\title{
Consent, Contestability, and Unions
}

\author{
Lars Lindblom \\ Umeå University
}

\begin{abstract}
This article provides a normative justification for unions. It discusses three arguments. The argument from consent justifies unions in some circumstances, but if the employer prefers to not bargain with unions, it may provide very little justification. The argument from contestability takes as its starting point the fact that employment contracts are incomplete contracts, where authority takes the place of complete contractual terms. This theory of contracts implies that consent to authority has been given under ignorance, and, therefore, that authority cannot be justified by consent. Contestability is a mechanism that can handle this problem for consent theory. It demands transparency, channels for voice, and a forum where contestations can be evaluated. This idea can be implemented in firms in different ways, but the argument from the separation of powers implies that unions are uniquely suited to implement contestability, since they are organized outside of the employer's domain of authority.
\end{abstract}

KEY WORDS: Unions, consent, contestability, separation of powers, incomplete contracts, employment contracts

$\mathrm{U}$ nions have made a comeback into the political debate. In the aftermath of the financial crises that started in 2007, researchers have looked for an explanation of the widening inequality in the US and elsewhere. Recently, Jake Rosenfeld (2014) suggested one such explanation, which identifies a link between weaker unions and growing inequality. This analysis was followed by research from the International Monetary Fund (IMF) that also found a connection between widening inequality and the development towards less union influence (Jaumotte and Buitron 2015). In the early days of the 2016 presidential campaign, the strengthening of American unions became an election issue (DePillis and Tankersley 2015). Perhaps this is a reason that public support for unions has recently grown quickly, albeit from rather low numbers and in a situation where levels of union membership are still low (Saad 2015).

This resurrection of unions as a topic of debate has been the work of social scientists. Philosophers have not participated in this discussion to any great extent, even though there seems to be a fairly clear-cut case to be made for the justification of unions from an egalitarian perspective, taking the connection between unions and equality as a starting point. This article will discuss the justification of unions, but it will not develop this potential egalitarian argument. The reason for this is not that there would be anything wrong with such a project. Rather, what I want to do in this article is to approach the issue from another perspective. My strategy is to start out from some standard views in economic ethics and economics that may not seem very supportive of unions and try to develop an argument in favor of them on this basis. The reason that I have chosen such starting points is, then, 
that I want to show that even from rather non-demanding premises one can derive a justification of unions. The economic theory I will use to describe the empirical terrain is the theory of incomplete contracts. In itself this theory may not seem very conducive to argument in favor of unions, and, moreover, I will combine it with a normative account which is often the one preferred by opponents to unions. The ethical starting point is the general Lockean approach to political philosophy and economic matters that has influenced libertarians and classical liberals as well as more egalitarian-minded liberals, with consent and the separation of powers taking center stage. However, since I will detect a problem with combining the theory of incomplete contracts and consent, I will also need to use a mechanism that is usually seen as being connected to republicanism: the notion of contestability. As I will argue, the use of this mechanism does not imply that one is also committed to the republican theory of liberty.

One way to approach normative issues regarding the labor market would be to think of them in terms of the freedom of association. If this freedom is in place and respected, would there be a need for further investigations of normative justification? There would. Freedom of association concerns the rights to form, join, and exit organizations (White 2013), but this in itself does not imply that unions would have any influence or effects, e.g., on working conditions. Employers may choose not to hire union members and refuse to bargain with unions. Indeed, if one looks to the International Labour Organization (ILO) conventions on unions, one finds that Convention 87 (ILO 1948), which protects the right to form and join unions, is complemented with the later Convention 98 (ILO 1949) that protects union members from discrimination and enforces a right to collective bargaining. A comprehensive justification of unions, then, should include reasons for why there is a right to join unions, but also present arguments for why discrimination of union members is wrong and why employers should bargain with unions. What I shall try to develop in the following, then, is a normative justification of unions by showing that there is moral reason to accept the rights to form unions and not to be discriminated against for union membership, and the duty for employers to bargain in good faith. These rights and this duty could, then, provide a basis for policy recommendations. However, I will not develop such recommendations here, but rather focus on the prior issue of the normative justification of these rights and duties with regards to unions.

I will discuss three arguments in favor of unions. The argument from consent is the topic of section 2 and says that if employer and employee agree to collective bargaining and labor rights, then this form of unionism is justified. This could be thought of as the libertarian argument for unions. However, when employer and employee do not agree on issues regarding unionization, other arguments can come into play. The argument from contestability takes the economics of the employment contract as its starting point. In section 3, I explain this theory of economics and how it implies that employment contracts are incomplete contracts. The reason that parties opt for this kind of contract is that they are faced with decision-theoretic ignorance with regards to the future. In the place of complete terms, there is authority. The economic explanation of authority is that when the unforeseen happens, someone must decide what to do, and this is the employer. However, this theory implies that 
consent to acts of authority has been given under conditions of ignorance. It follows that the course of action that the employer chooses to take cannot have been justified by consent. In section 4, I will, then, argue that Philip Pettit's mechanism of contestability provides the needed method of justification $(1997 ; 2001 ; 2000)$. From the perspective of contestability, what is needed in order to justify employer authority is a real possibility to contest employers' decisions, which means that there must be transparency and effective measures in place to make grievances heard and that proper hearings of contestations must be guaranteed.

This argument shows that there should be a mechanism for influence for employees within the employment relationship, but does not show that this mechanism must be a union. There are many organizational solutions used within firms to allow employees to make their voices heard. For example, in some countries employers have organized so-called company unions, entities designed as unions but under control of the employer, as an alternative to actual unions (cf. Dray 2010, 410-415). Is there any reason to prefer real unions over other alternatives? One such reason has to do with the argument from the separation of powers, which I will discuss in section 5. This idea is mostly discussed with regard to the design of constitutions, but it generalizes: power must be checked by power. Since we know from other contexts that the separation of powers can do its intended work, and since actual unions are not under the power of the employer, alleviating the problem of the employee being in a kind of coercive situation, which is the case when authority cannot be justified by consent, we have reason to prefer unions over company unions. More generally, we have reason to prefer that unions are in place, even if internal grievance mechanisms have been implemented. The claim I make in this article, then, is that the combination of the arguments from consent, contestability, and the separation of powers amounts to a normative justification of unions.

\section{CONSENT}

A straightforward way of achieving justification of unions would be to show that they gain their moral standing through consent. In this section, I will outline the theory of consent and then do two things. First, I will investigate the implications of this kind of theory for unions, and second, try to indicate the strengths and weaknesses of this approach in the context of the labor market. This latter step will also set the stage for the argument of the next section.

That main idea of consent is deceptively simple. Market transactions are justified by informed and voluntary agreements between the parties, which means that if employer and employees agree to collective bargaining, then unions are justified. I call this idea deceptively simple, because, as we shall see, in order to make it operational one must deal with many complex moral concepts. A good place to start analyzing these issues is the following well-known quote from Milton Friedman: "The possibility of coordination through voluntary cooperation rests on the elementary-yet frequently denied-proposition that both parties benefit from it, provided the transaction is bi-laterally voluntary and informed" $(1962,13) .{ }^{1}$ To get the ideal of consent off the ground, we need to define the conditions of voluntariness 
and information. What may be less apparent is that doing so will raise issues concerning the definition of coercion, and to some extent also the matter of the moral grounding of the mechanism of consent.

Voluntariness and information are each necessary and jointly sufficient conditions for justification by consent. If a choice is not voluntary, the decision to accept an agreement cannot be said to be the agent's own, and if the information condition is not fulfilled, then the agent will have been unable to know the content of the agreement, and, again, the decision cannot be said to be the agent's own. Together the conditions guarantee that an agreement is grounded in the authentic choices of the parties. But what do these conditions say? Let us start with the information condition. There are few developed versions of conditions for information in the literature, but Tom Beauchamp and James Childress (2001) have presented one promising suggestion in the context of medical ethics. They argue that medical professionals must disclose "those facts or descriptions that patients or subjects usually consider material in deciding whether to refuse or consent to the proposed intervention or research" $(2001,81)$. For this to become a condition of information, it must, of course, be generalized. If we replace the terms related specifically to medicine, and the demand that a specific agent should provide the information, we get the following: In order for agents to be informed they must have access to those facts or descriptions that such agents usually consider material in deciding whether to refuse or consent to the proposed act.

However, as it stands, this condition is consistent with the agent having no information at all. If such agents usually ask for no information, they could be fully ignorant, while counting as informed. We cannot know everything, so the relevant question would be: What is informed enough? Joel Feinberg $(1986,115)$ suggests two criteria for when the agent lacks information to such a degree that choice cannot be said to be autonomous:

Not because of ignorance (mistake) of factual circumstances.

Not because of ignorance of the likely consequences of the various alternatives open to him.

Feinberg's conditions put a lower bound on what level of knowledge the agents must have, and show that our condition of information must include some criterion of minimal information. Let us, then, call a person who abides by Feinberg's demands on information a reasonable person. This person would also, in line with Beauchamps and Childress's suggestion, require having access to such information that agents usually demand in addition to this minimal demand. A reasonable person would want to know the basics of what he or she is consenting to. We can, then, reformulate the condition on information: In order for agents to be informed they must have access to those facts or descriptions that a reasonable person considers material in deciding whether to refuse or consent to the proposed act.

Voluntariness is usually taken to mean that the choice is made in the absence of coercion. What, then, does coercion mean? There are many different accounts of coercion, but here I shall focus on Robert Nozick's theory. There are two reasons for this focus. His classic article "Coercion" (1997) can be said to have started the 
modern debate on this concept, and is, hence, very influential. The second reason is that it seems more interesting to develop an argument in favor of unions on the basis of a libertarian theory, than by using theories that have more egalitarian implications. ${ }^{2}$

Nozick explains his account of coercion with the help of the following, congenial, example: "You threaten to get me fired from my job if I do A, and I refrain from doing A because of this threat and am coerced into not doing A" $(1997,16)$. According to this view, there is coercion when one agent threatens another with some negative outcome if that latter agent does not take some specific course of action, both agents know that this threat has been made, and the latter agent takes this specific course of action due to this threat. However, this might seem to make ordinary bargaining over the price of a product into a case of coercion. If I say I won't buy your car, unless you lower the price, I seem to be informing you that I may bring about the adverse outcome that you will be stuck with your car. In order to not run into that kind of a problem, a baseline must be defined. For Nozick, this baseline consists of a person's rights. A decision is voluntary, according to this view, when it has been taken in a situation where there has been no breach or threat of breaching a person's rights in order to make the person take that decision.

With these conditions of voluntariness and information in hand, one can quite straightforwardly develop a justification of unions where cooperation between employers and unions can come out as a kind of "capitalist acts between consenting adults" (Nozick 1974, 163). For any transaction, it is the case that if the agents act within their rights and both parties are informed and not coerced, consent will imply that the transaction is morally justified. For libertarianism, the only fundamental principle of economic ethics is consent, given, of course, that initial property rights have come about in a proper manner. This view implies, for instance, that if this is my widget and you are prepared to pay my asking price, and if both of us are informed and uncoerced, then the trade of the widget will have moral justification. The same goes for services. If I agree to dig a hole in your backyard, and the two conditions on consent hold, then we are morally permitted to carry the agreement out. These examples concern interactions between just two people, but the approach generalizes to situations where many people are involved. If my friend and I decide to start a hole-digging company, and each of us consent properly to the terms of contract, we achieve libertarian justification for our company. Consent between our firm and prospective customers is likewise unproblematic. As long as each party is informed and acts voluntarily the resulting agreement is justified by consent. Now, assume that my friend and I did not start a company, instead we decided to cooperate by starting a union, what would the principle of consent imply? First, if my friend and I consent to forming a union, then the union is fully justified on a libertarian perspective. No one has standing to complain about it. Second, if we have started the union, informed the prospective employer, and all parties then agree to a contract that includes good faith bargaining and non-discrimination, then this union will be fully justified. Proponents of libertarianism should support unions to the same degree as they support entrepreneurs or firms.

It may seem surprising that I argue that libertarians should support unions, since many of that theory's most well-known proponents, like the Friedmans (1990) and 
Hayek (1960), have been rather vocal opponents of unions. This is where the issue of the moral grounding of consent becomes important. The arguments of the Friedmans and Hayek have to do with the allegedly negative consequences of unions. This criticism rests on a different kind of libertarianism than Nozick's theory, and they also differ from the characterization that I gave above. The difference is that between a rights-based and a consequentialist, or welfarist, theory. The version of libertarianism I am concerned with here is the former. As was noted in the introduction, much has happened recently in the social science of unions. These developments, of course, affect what consequentialist conclusions to draw regarding unions. This, in turn, makes it a much too comprehensive project for this article to evaluate consequentialist criticisms of unions. If these new results turn out to be correct, there seems to exist a quite straightforward consequentialist or welfarist justifications of unions. In this article, however, I would like to focus on the more demanding case for justifying unions. Moreover, to be able to evaluate consequentialist arguments, we must have a clear view of possible rights and duties of employers and employees. For example, if there is reason to think that people have rights, such as the right to join a union, then this may constrain the reach of consequentialist reasoning.

However, the conclusion I have reached is much less helpful to proponents of unions than it may seem. Consent-based theories, like libertarianism, can also imply forceful restrictions of unions. There are cases where libertarianism implies that it is wrong to start unions. If my friend and I are already employed when we get the idea to start a union, and we have signed an employment contract with a clause that says that we agree not to start a union, then we are obligated to refrain from doing so. Such so-called yellow dog contracts are standardly denied legal standing in practice, but would have moral justification on a very through-going consent-based view. There are also cases where non-discrimination of union members is condoned by libertarianism. If employers either decide to never hire union members or only agree to contracts where they retain the right to fire on this basis, then discrimination turns out to be fully justified. Finally, good faith bargaining is a more substantive principle of bargaining than the two conditions of information and voluntariness, since it demands that bargaining is undertaken with a specific motivation. To bargain in good faith is to bargain with an intent to achieve an agreement (Yates 2009, 83), which arguably would imply that one bargain on the basis of reasons relevant to the context of the agreement. To not bargain in good faith is not in conflict with voluntariness or information, since it neither involves coercion nor the suppression of information, and therefore good faith bargaining will only gain libertarian justification if the parties happen to want to bargain in good faith.

The justification of unions will, then, depend crucially on the self-interested reasons of those who may stand to lose economically by their existence. If employers do not want to deal with unions, they can choose to bring about a situation where unions lack moral justification, either fully or in part. There are several approaches that one could take to this conclusion. One would be to say that since some consentbased theory, e.g., libertarianism, is correct, the conclusion is morally correct as well. Another would be to say that this shows that theories like libertarianism have a moral problem with power, and that this implies that such theories are morally mistaken. 
In the following sections, I will take a third approach. I will try to show that we need more tools than can be provided by consent to deal satisfactorily with the labor market, and that when one supplies such a mechanism, a rather strong argument for unions results.

\section{ECONOMICS OF THE EMPLOYMENT RELATIONSHIP AND THE MECHANISM OF CONSENT}

To understand why a normative theory of the labor market needs further tools than those provided by consent, we will now turn to the employment contract. ${ }^{3}$ In this section, I will try to show that the economics of contracts, and in particular the explanatory role that ignorance plays in that approach, implies that consent cannot play the role of the sole normative mechanism for the sphere of employment, since it will leave employer authority without normative justification.

The general idea of a contract is straightforward. The parties freely agree to a set of terms that spell out what each party should and is entitled to do. For instance, the terms might say that I am obligated to turn over the deeds to the house to you, and you should give me a specific sum of money. This is the kind of an agreement consent can justify. However, employment contracts are different from such standard contracts in that they are incomplete. They do "not specify each party's obligations in every conceivable eventuality" (Vandenberghe 2000, 552; cf. Cahuc, Carcillo, and Zylberberg 2014, 325-328; Bowles 2004, 233-238). What might be the point of not having a complete contract? The answer is that it is a rational response to uncertainty. To see this, we can enlist the help of transaction cost economics. This branch of economics focuses on how the parties design contracts to deal with such costs. Specifically, it "deals with how rights to decide, control and coerce are allocated between the parties" (Brousseau and Glachant 2002, 15). A core idea is that what happens in a market system is not always decided by the market's price mechanism. The internal decision problems of organizations may be more efficiently solved by other means. An incomplete contract enables the parties to deal with the transaction costs brought about by uncertainty more efficiently than the market could. This reasoning illustrates how "the underlying theme for transaction costs is the notion of ignorance" (Allen 2000, 906).

Ignorance costs in at least two ways: first, there are costs caused by the impossibility of foreseeing all relevant future events and forming proper responses to these, and, second, there are the prohibitive costs of actually negotiating such a complete contract, even if all future states of the world were possible to foresee (Milgrom and Roberts 1992, 330). The parties to the employment contract are dealing with situations where the future is unforeseeable, and try to handle this by agreeing to terms that say that someone will get to decide when the unforeseen occurs. This is, then, what provides the economic motivation for authority in the firm. This theory is general and also explains the construction of employment contracts with regard to state-run organizations, cooperatives, or socialist firms. Milgrom and Roberts state the solution provided by incomplete contracts succinctly: "The decision mechanism in the employment contract is basically that the boss can order the employee to do anything that is not explicitly forbidden by the contract's terms or by law" $(1992,330)$. 
According to the economics of contract, then, ignorance of future contingencies is a defining feature of employment contracts. In this context, it is important to distinguish between choices under different levels of information. Standardly, we distinguish between choices under certainty, risk, or uncertainty (Luce and Raiffa 1957, 12-15). In a decision under certainty, everything is known. If you choose the bar of chocolate, then you will get the bar of chocolate. For a choice under risk, the agent has access to the possible outcomes and their probabilities given the set of options. In a choice under uncertainty, the agent lacks these probabilities, but there is still a full set of alternatives to consider. In all these cases, the agent will have access to information about what will happen, and the Feinberg criteria can be satisfied. However, there is a further kind of choice to consider. Sometimes a choice has to be made in a situation where the agent has neither access to information about possible outcomes nor probabilities. This is choice under ignorance or, with its technical name, radical uncertainty (Knight 1921; cf. Resnik 1987, 13-17). This is the kind of decision problem the parties to the employment contract are facing. They lack information about factual circumstances, which means that Feinberg's first criterion will not be satisfied for acts of authority in those circumstances. Since they do not have access to information concerning the set of possible outcomes and therefore lack knowledge about likely consequences, it is also the case that the second of Feinberg's criteria cannot be satisfied.

Ignorance, then, explains why firms have the design that they have and why there are bosses. This way of organizing production is more efficient than bargaining each time something unforeseen happens, or than alternating between different parties being in charge. ${ }^{4}$ There are two theories as to why the owner of capital takes this role of authority: that he or she bears a greater risk than the owners of human capital, or that he or she has a stronger interest in the reputation of the firm (Milgrom and Roberts 1992, 330-332). ${ }^{5}$ But, in what sense is the decision making of the employers to be understood as a form of exercising authority? A dissatisfied employee can quit, rather than being forced to do something he or she objects to doing. The answer is, of course, that it is costly to quit a job. You lose your firm-specific human capital and will face transaction costs when searching for new employment. And if the efficiency wage theory is true, the employee also loses rents by quitting. This theory says that one can bring about Pareto improvements by paying wages over the market price, since this brings about extra effort from employees (Milgrom and Roberts 1992, 250-261). Since the boss can bring about these kinds of costs by firing the employee, and the costs that the employee can inflict on the employer by quitting are standardly much less heavy, the latter is in a position of authority over the employee. ${ }^{6}$

Here the reader may object that this is a very theoretical account of what happens on the job and with regard to unions, and that there is more to authority than it can convey. For instance, it might be the case that some people desire to have authority and use the means at their disposal to get it. Maybe a reason that the boss is in charge is that he has used his market power to demand that he gets to make decisions. Such an explanation of authority may well be true in some cases, and may then further strengthen the argument for unions. However, there is reason to focus on incomplete contracts, since they are an inherent part of the employment relationship. Even under 
the most ideal, egalitarian, or other, circumstances, this will be a part of how the labor market functions.

Another objection could be raised from the perspective of the work of Christopher McMahon $(1994 ; 2013)$. He argues that consent also stands in need of justification if it is to justify employer authority, and presents a theory where it is justified by being a part of a larger system aiming to pursue the common good. This seems both plausible and fruitful, but I shall not follow this line of thought here. The reason is, as I mentioned in the introduction, that my focus is on developing an argument from premises that are usually taken to provide ground for being skeptical of unions. Moreover, to the degree that consent will play a role in such a theory, the arguments of this article will still have normative relevance.

Now, if this account of the employment relationship is correct, then ignorance plays a very important part in explaining the organization of the labor market. However, it also creates a problem of consent. Since consent must satisfy the information condition, and authority is a response to ignorance, the theory cannot justify employment contracts. For each case of rationally motivated authority, it is the case that the subject of this authority was ignorant of the conditions leading up to this instance of authority. The motivation for authority comes from situations where Feinberg's two criteria cannot be satisfied. It follows, then, that the course of action that the employer chooses to take cannot be justified by consent. Since employer acts of authority are explained by ignorance, they cannot be justified by consent.

It is important to notice that this argument claims that consent, as the sole mechanism for justification, cannot justify acts of authority. The claim is not about the substantive justification of courses of action, or other mechanisms of justifications than consent. To see how this matters, consider the following example. Since you started at the department, you have taught a course on Plato, but this year the head of department says that due to changes in student composition and faculty qualifications, you should teach the course on the philosophy of mathematics, for which you are equally suited. This has never before been discussed and is, hence, news to you, and you refuse on the grounds that you never consented to teach this course. If the change of course has never been discussed, then it is the case that the consent condition of information will not be satisfied. From the standpoint of substantive norms, one could say that a university professor should teach the courses for which he or she is suited and for which the department has a need. However, even if this norm is true, and you should, for this reason, teach the course, this does not show that you have consented to give the course. At most it shows, that there are other, substantive rather than procedural, reasons than those of consent, which might speak in favor of you giving the course. ${ }^{7}$ Fully consent-based theories like libertarianism reject that these other reasons play a role for the justification of authority.

An implication of the claim that the information condition is not satisfied is that the principle of volenti non fit injuria cannot be in force with regard to acts of employer authority. This principle says that one is not wronged by actions to which one has given one's consent. ${ }^{8}$ Feinberg explains the principle in the following manner: "A person can indeed be harmed by what he consents to, in the sense that his interest may be set back, but he cannot be wronged" (1986, 100; cf. Feinberg 1984, 115-117; 
Goodin 2006). In order to illustrate, let us return to the example from Nozick: the threat of being fired. The moral difference between a man on the street threatening to get a person fired from his job and an employer issuing a warning that one may be dismissed is that in the latter case volenti is in effect. If volenti is not in effect, then such a threat within the confines of the employment contract comes out as a wronging. The idea, then, would be that since one has consented to the authority of the employer, one has given him or her permission to bring about outcomes that would, without such consent, count as unjust. However, since it cannot be the case that proper consent has been given to acts of employer authority, volenti cannot be in effect. This, in turn, means that the employee is in a coercive situation within the employment relationship. If acts of authority bring about unconsented to and adverse outcomes for the employee, then these will amount to wrongings. There remains no relevant moral difference between a threat of having someone fired and employer authority. This has the further implication that what seems like the obvious solution to this problem cannot work. If the reason that volenti does not apply is that the relevant information was lacking at the time of the agreement to the employment contract, it would seem that problem would be solved if that information was provided. However, since the employee is now in a coercive situation-the employer can bring about unconsented to adverse outcomes, by, e.g., firing the employee, which undermines voluntariness-what is needed is a solution that handles both conditions on consent, and not only the information problem. A problem of coercion is not solved by the provision of more information; we must look elsewhere for that.

It is important to see exactly what the problem is (i.e., that acts of authority cannot be justified by prior consent). This does not mean that many other aspects of the employment relationship cannot gain justification through consent. The argument presented does not imply that there is something wrong with somebody doing work for someone else. The problem is authority. Moreover, the argument does not imply that there are no aspects of the employment contract that can gain justification by consent. Agents can have access to those facts or descriptions of acts that a reasonable person would usually consider material when deciding whether to agree to such contracts. They can be fully informed about policies, product lines and personnel at the time of entering an employment relationship. In this respect, consent does important normative work. But, for consent and volenti to do their work, information must be about the right things. So there could be a presumption in favor of the decisions the employer make, but when he or she does take these decisions, we find ourselves in situations that were unforeseen at the signing of the contract. The specific acts of authority undertaken under such circumstances cannot gain justification through prior consent.

This analysis of consent and the information condition may seem counterintuitive. Especially, this may be the case if one applies the analysis to other contexts than the labor market. For instance, does this not mean that one cannot consent to marriage? ? $^{9}$ The answer is that one can consent to the relationship of marriage, but this does not imply that this consent justifies authority or that it brings volenti into effect with regards to acts of authority within the marriage. If your spouse spends all of your common vacation funds at the race tracks, he or she cannot claim that you 
have given your consent to this course of action. Worse examples from the history of marriage can also be devised. The point is that one can enter into relationships by consent, without thereby also giving a carte blanche in terms of volenti for the exercise of authority. ${ }^{10}$

This means that libertarians must look for another way to justify employer authority. Or they could bite the bullet; if the only fundamental principle of economic ethics is consent, and authority based on incomplete contracts is incompatible with this principle, one way to go would be to say so much for employment contracts. If there must be informed consent to every management directive, then it would be impossible to form incomplete contracts and therefore to have employment contracts in any standard sense. In this way, libertarianism is incompatible with capitalism. It lacks the appropriate normative mechanism to handle core institutions of market economies. But rather than taking this radical approach to the ethics of employment, we could look into whether there are other forms of justification that can complement consent. In the next section, I will try to show both that the mechanism of contestability can provide the needed justification and that unions provide an important way of implementing this mechanism.

\section{CONTESTABILITY}

In this section, I will present the mechanism of contestability as developed by Philip Pettit $(1997,2001,2000)$ and argue that it can solve the problem of justification brought about by incomplete contracts, by providing another way to get to voluntary and informed agreements. I will also try to show that if there is a case for contestability, then this argument can also be used to justify unions. Pettit's core idea is that "what matters is not the historical origin of decisions in some form of consent but their modal or counterfactual responsiveness to the possibility of contestation" $(1997,185)$. This means that if one has a real possibility to contest a decision and refrains from contesting it, then the decision is justified. Three requisites must be satisfied for there to be such a real possibility: a basis for contestation, an opportunity for voice, and a forum where contested issues can be settled.

It is well known that Pettit is a proponent of the republican account of freedom, which interprets this value as non-domination. The idea is that a person is free when no one has the capacity to interfere on an arbitrary basis with his or her actions. This is a controversial idea, and one that many liberals and libertarians reject. Since contestability is a core part of Pettit's republican program, one could suspect that my argument in the following will also implicitly rest on this notion of freedom. To see why this is not the case, consider the following quotation from Pettit:

Whether a relationship sprang originally from a contract or not, whether or not it was consensual in origin, the fact that it gives one party the effective capacity to interfere more or less arbitrarily in some other's choices means that one person dominates or subjugates the other $(1997,62)$.

What Pettit says here is, of course, congenial to the reasoning in this article, but the argument that I will present differs from republicanism at two important points. 
First, I will not say that whether the origin of an agreement is consensual or not, contestability should come into play. What I have argued above is that consent cannot do all the work it is usually thought to perform; even if it can provide some justification for the employment relationship, it cannot do so for specific acts of authority. I will use contestability as a mechanism for justification that solves the problems we found in relying solely on consent as the approach to justifying employer authority. Second, and relatedly, my argument does not use the ideal of non-domination as a premise. Republicanism might be the correct account of freedom-I do not take sides on this issue here - but even on a more standard account of freedom, consent runs into problems when it encounters incomplete contracts. My argument starts from the idea that if there is a method of justification that relies on agents being informed and acting under fair circumstances, and that handles the problem with incomplete contracts, then we have reason to turn to this method for justificatory purposes. This, rather than republicanism, is the basis of my argument. ${ }^{11}$

Let us turn, then, to what contestability implies. A basis of contestation consists of a standard of cooperation. This standard of cooperation makes demands that authorities should "decide on the basis of suitable considerations and to make clear which considerations are moving them" (Pettit 1997, 188). Clearly, what counts as suitable considerations will vary between the context of government, which is what Pettit focuses on, and the workplace and the case of unions, but especially given the problem of justifying acts of authority, it seems reasonable to demand that the reasons for a decision should be appropriate to the kind of organization the decision concerns. That there should be measures in place that enable those who are affected by a decision to identify the reasons for it and to contest it if they see fit, means that transparency is a fundamental demand of the ideal of contestability. In the workplace, this would mean that employees have a right to information regarding decisions that concern them. In this way, contestability will remedy the problem of information for the ideal of consent, but as I noted above, information does not help us with the problem of coercion. The next two requisites will, however, help solve this problem.

That there must be a way to give voice to one's concerns, gives rise to the requirement "that for any way in which public decision-making may offend against someone's interests or ideas, there are means whereby those interests or ideas can be asserted in response" (Pettit 1997, 190). This is phrased in terms of public decision making, but the point generalizes to economic decisions as well and implies that there must be mechanisms in place so that employees can give expression to their worries or complaints. Moreover, it means that the workplace must be organized so that it is possible to voice concerns. This provides support for such measures as employee hotlines and ombuds, but, as I shall argue in more detail below, especially for unions. They are organized precisely to give employees the opportunity for voice.

However, being able to voice one's misgivings about a decision does not necessarily change or even affect it. There must also be some way to influence acts of authority. This is where the notion of a forum comes into play. There should be a forum where a proper hearing of complaints are guaranteed, and where fair decisions are taken with regards to those contestations. Authorities should not be able 
to "ignore certain challenges that are raised against them. Such bodies should be required to answer for how they behave" (Pettit 1997, 195-196). This brings to mind such mechanisms as parliaments or courts, but Pettit notes that there may be other ways of organizing contestability that are more suitable in different circumstances. Collective bargaining could be such a mechanism.

To provide a justification of unions is to give justificatory reasons for the rights to form unions and non-discrimination of union members and the duty of good faith bargaining. Moreover, the theory we are looking for must be able to handle the problem concerning acts of employer authority that created difficulties for the consent-based theories, such as libertarianism. Let us, then, turn to how unions can implement contestability and thereby solve the problem of consent. Starting with the basis of contestation, the demand for transparency solves, as was noted above, the problem of information. With transparency in place, employees will be informed about the policies and decisions that affect them. This aspect of contestability demands that parties make clear the reasons that are moving them when making decisions. This, in turn, underwrites some preconditions for good faith bargaining and provides a link between contestability and unions.

Now, it is quite obvious that there is a connection between unions and voice. Part of the purpose of a union is to enable its members to express their views or demands and to make their voices heard. The fact that a group of people, rather than an individual, expresses itself when a union speaks out makes it more probable that what is being expressed is also heard. If we want to get serious about voice, we should have mechanisms that implement it efficiently. Therefore, a right to form unions would seem to follow from the implementation of contestability. This indicates, furthermore, that the right to strike should be protected as a part of the implementation of the mechanism of contestability, since such a right safeguards the possibility to make one's voice heard. ${ }^{12}$ Moreover, discrimination of union members would undermine this mechanism for voice. If employees fear that they will be retaliated against if they speak out, they will clearly be hesitant to voice their concerns. Nondiscrimination of union members is, therefore, a demand of the ideal of contestation. These two points imply that the standard of cooperation should include a norm against the discrimination union members and respect for the right to form unions.

Finally, let us turn to the notion of a forum. With voice and good faith bargaining in place, we also have a way of handling the problem of coercion. A forum where good faith bargaining takes place is a noncoercive arena for agreement. To be clear, not every actual case of collective bargaining is noncoercive, but the full implementation of contestability, including stable unions, would make possible such a state of affairs. Both parties would be aiming to come to an agreement, while having access to information, and in circumstances where the rights to join a union and to contest are respected, which would handle the problem of coercion. This is comparable to the bargaining situation prior to the agreement to the employment contract, where we usually assume that there is sufficient voluntariness. The parties retain a more or less equal standing. Implementing contestability, therefore, provides a solution to the problem of acts of employer authority and coercion. This solution should be 
attractive to the libertarian bothered by the problem of combining consent and incomplete contracts, since it, like a consent-based approach, is based on a mechanism that protects voluntariness and satisfies the information condition. By implementing the requisites for contestability, we secure a situation where the employees can participate in the decision making about contestation under informed and uncoerced conditions. Good faith bargaining demands that one tries to come to an agreement and that one argues on the basis of reasons that are appropriate to the context. If all parties have information, can voice their concerns, argue on the basis of suitable reasons, and intend to come to an agreement, then we have a method that can provide free and informed agreements. In this way, contestability recreates the conditions for consent in a social context, in a way that should be attractive to libertarians. ${ }^{13}$ The ideal of contestability can provide a justification of unions.

One could, of course, wonder about how to think about a case where a person contests a decision and loses in the forum. The problem we found with consent was that acts of authority comes out as coercive, but would not a person who loses a contestation also be coerced? What we should look for, in order to reply to this worry, is an account of justification that applies to parties of formed social relationships. If one has agreed to be a part of a relationship, one should also be ready to agree to a common solution to handle problems that may appear. Contestability delivers such a method. If this approach is accepted, and given that it solves the theoretical problem brought about by incomplete contracts, there is reason to do so; one could still say that a person's interests are set back by losing a contestation, but that this will not amount to harm in the moral sense. In a social context, having one's case decided by a fair, un-coerced, and transparent social process is not coercive, but something one should be prepared to accept.

Not only is there reason to think that contestability is compatible with the kind of states we can observe in many parts of the world today, but it is also, unlike consent-based theories in the vein of libertarianism, consistent with market economies as we know them. Since, contestability provides counterfactual justification, acts of authority that are not contested will be justified. There is no need for consent to each management directive. Moreover, for contestability to be implemented, one needs to put in place mechanisms for solving conflicts, and there will also be incentives for employers to make decisions that are acceptable to employees and in that way avoid contestations. To the degree that we think that both moral justification of acts of authority and a functioning market economy are important, we have reason to accept contestability as a normative mechanism.

We need unions to implement an ideal that solves the problem of justification brought about by incomplete contracts. However, there is a problem; other methods could also be used to implement contestability, such as ombuds, company unions, or forms of participatory management. This raises the question of whether unions can be justified if such other methods are in place. We lack an argument for why unions are uniquely justifiable. In the next section, I shall attempt to show how another mechanism from the Lockean tradition - the separation of powers-can provide such an argument. 


\section{THE SEPARATION OF POWERS}

This section aims to do three things. First, to set the stage, it presents an account of the role of unions in a market economy. This account will give pride of place to a mechanism for separating and balancing power. Second, it aims to explain the theory of the separation of powers. Third, it will combine the results of the previous sections with this account of the separation of powers to argue that unions are uniquely justifiable as a mechanism to implement contestability.

In his classic American Capitalism (1993), John Kenneth Galbraith develops an analysis of capitalism and why it tends to deliver prosperity, which in a way rests on the notion of the separation of powers. He argues that the answer can be found in what he calls the theory of countervailing power, and in it unions play a prominent part. This theory starts from the observation that on the standard account of the market, self-interest, and market power is held in check by competition. If a company charges exorbitant prices, its competitors can take over its market share by selling their products at a lower price. If an employer offers wages that are too low, other employers will take advantage of this when hiring. Competition works for the common good by checking power with power on the same side of the market (i.e., the power of one employer is checked by other employers). However, there is another mechanism for harnessing power that can be seen in any market system, and this is power wielded on the opposite side of the market, as when the power of suppliers is checked by purchasers. This mechanism tends to come into play when competition fails to do its intended work - when oligopoly or monopoly characterizes the market. If a de facto monopoly in, say, manufacturing develops, the buyers of the product in question have at least two reasons to band together. First, the monopolist will have market power and can set prices as he or she sees fit. It makes economic sense, then, to try to counteract this kind of power by, e.g., coordinating purchases. Second, the monopolist will be able to extract rents, of which the buyers, if they wield countervailing market power, could get a share. When market concentration emerged in the area of rubber tires, it was met with the development of large chain stores, such as Sears \& Roebuck, that had countervailing power, and hence could extract some of the rents and bargain about prices on a more equal footing than a mom and pop store would be able to (Galbraith 1993, 110-114, 119).

However, Galbraith claims that it is in the labor market that the clearest examples of countervailing power can be seen. Since employees are in a situation of "comparative immobility" (Galbraith 1993, 114) in relation to employers, due to the costs and difficulties of finding new employment, the latter tend to be in a position of power over the former. The employees will have reason to form unions, since they can then counteract employer power and also gain a share in his or her rents. According to this theory, it is no coincidence that there is a higher degree of union organization in markets where there is oligopoly or monopoly, than in less centralized markets. When there is a lack of competition, unions can step in to restrain market power and hence increase efficiency. This shows that there is a role to play for a kind of separation of powers through unions in market economies. 
Galbraith's theory aims to explain the functioning of capitalism, but it is quite easy to see how one could develop a justification of unions from his reasoning. If unions play an important role in market economies and, therefore, serve the common good, there is a rather clear-cut consequentialist argument for unions. There is also an egalitarian argument in the vicinity. Nobel laureate Robert Solow (2015) recently argued that one cause for the growing inequality in the US is that the weakening of unions has made it more difficult for workers to get a share of the rents that come from having a big presence on the market. This argument for unions would then be that they are an important mechanism for achieving a more egalitarian distribution of income. Both these approaches to the justification of unions are promising, but what we are looking for here is an argument that connects with the problem of coercion, and, in the following, I will develop one.

The normative counterpart to the empirical theory of countervailing power is the notion of the separation of powers. It has a distinguished pedigree in political philosophy. Among its proponents are Locke (1980), Kant (1983), and, of course, Montesquieu (2011). The general idea is simple: power must be balanced by counterpower. However, this ideal consists of two parts (cf. Zuckert 2012, 352-363). First, there is the principle that the proper scope of power implies that different powers should be exercised by different and appropriate agents. Since the powers of the executive, the legislature, and the judiciary are different and make different demands on the agents wielding them, these powers should be handled by different kinds of agents. Second, to ensure that neither agent oversteps the proper bounds of their power, the system of government must be designed so that different powers check and balance each other. The goal when designing a constitution is to find a solution that allows each branch to do its work effectively, while finding balances and checks between branches such that no one oversteps the bounds of their proper authority. Our goal in this section is to see if there is a similar solution available for the employment relationship. This will enable us to show how unions are uniquely justifiable as a way of implementing contestability.

There are numerous alternative mechanisms for implementing contestability, and it is infeasible here to go through them all. What I shall do, first, is to compare unions to what I perceive to be their closest competitor, company unions, and try to spell out why we have reason to think that actual unions are preferable as a way on realizing contestability. ${ }^{14}$ I will then make some further comments about four other approaches, two of which can be thought of as individualist, and two with a more collectivist slant. As we have seen, the major difference between a company union and a union of the standard kind is that the former is organized and run by the employer. Other than that, the two different forms of unions are supposed to fulfill the same functions. This is one sense in which they are close competitors; another way is that since they have this similarity, it would seem that if one is justified the other would probably be close to being justified as well. To carry out its function, a company union would have to provide a basis for contestability, channels for voice, and a forum. If a company unions could perform the same functions as actual unions, this would seem to make the latter unnecessary, and, hence, not uniquely justified by the argument from contestability. However, I shall argue that even if they could 
perform the tasks associated with these functions, we still have reason to prefer actual unions over company unions.

To see why, let us turn to what may be the politically most important account of the separation of powers, The Federalist Papers (Rossiter 1961), and the motivation found there for this principle. The argument is laid out by James Madison in papers 47 to 51 . He makes it very clear that the aim of the principle is to protect liberty against tyranny: "The accumulation of all powers, legislative, executive, and judiciary, in the same hands ... may justly be pronounced the very definition of tyranny" (1961, 301). The reason that such centralization can be denounced as tyranny is partially because that term can be understood as unrestrained power, but also because the probable consequences of designing decision making in such a manner. To clarify this risk, Madison turns to Montesquieu and quotes what probably are some of the most discussed sentences with regards to the separation of powers:

Were the power of judging joined with the legislative, the life and liberty of the subject would be subject to arbitrary control, for the judge would then be the legislator. Were it joined to the executive power, the judge might behave with all the violence of an oppressor. ${ }^{15}$

These considerations lead to the conclusion that when designing a system of governance one must make sure that there are checks on different kinds of power and a balance between them. Commitment to the separation of powers leads to many different policy demands. One example is how salaries should be set in the governance system. It is inconsistent with the separation of powers, notes Hamilton in Federalist 79, that the judiciary can decide the salaries of judges, since this would give the former unbalanced power over the latter. He continues: "In the general course of human nature, a power over a man's subsistence amount to a power over his will" (1961, 472, emphasis in original). When someone has this kind of influence over one's livelihood one is not fully free, since the other party can force one to follow their demands. The conclusion must be that we should avoid unchecked power in both its institutional and monetary form.

From this discussion about motivations for the separation of powers, two reasons to prefer actual unions to company unions emerge. First, if Madison and Montesquieu are correct about the risks of centralized power, then this supports actual unions, providing a decentralized method of implementing contestability, over company unions. Since what we are trying to solve here is the problem that management directives come out as cases of coercive authority, it would seem foolhardy to attempt to handle this problem in a way that makes us dependent on the power of the employer. Unless employer power is checked, the problem of coercion is not fully resolved, since this leaves the employee in a similar kind of situation to the one that provided our starting point. This speaks in favor of actual unions. Second, if Hamilton is correct, and power of income is a kind of power over a person, then we should prefer a system of contestation that is less dependent on the party that has power over subsistence. The employer has such power not only through influence on wages or salaries, but also through his or her ability to make hiring and firing decisions. 
Actual unions are better positioned to balance this power than company unions, especially if they have access to well-financed strike funds. ${ }^{16}$ This amounts to a further reason to prefer actual unions to company unions.

The general point is that power should be checked and balanced. But what are the distinct powers in the case of the employment relationship? There is the power inherent in the authority of the employer, and there is the power of the employee to either agree to the conditions of employment or contest them. ${ }^{17}$ The question is how to best balance and check, and the choice we are considering is whether it should be done within the organization under control of the employer or not. There seems to be ample reason to choose unions over company unions as a robust way of implementing contestability. They are not under the control of the party whose power we aim to check. Therefore, we should choose to design the checks on employer power outside the domain of the firm. Actual unions are, therefore, better situated to properly implement contestability for reasons given by the ideal of the separation of powers. This further argument for why unions are uniquely justifiable should be congenial for libertarians and others from the Lockean tradition who find the problem of consent and incomplete contracts pressing.

This conclusion concerns the comparison between unions and company unions, but one may wonder whether it generalizes? First, what about an individualist approach to contestability that instead of channeling contestations through unions were designed to give each employee a direct way of contesting decisions, perhaps through some ombuds function? Such a proposal runs into the same kind of problems as company unions did, since there is an obvious imbalance in terms of power, at least in the great majority of cases, between a company and an individual employee. A way of strengthening the bargaining power of the employee would be to let the contestation be settled in court. This would be a second solution, but it seems problematic from the perspective of finding a method that is consistent with an efficient market system. Having employees contesting employer directives in the judicial system would make companies difficult to run and hamper their decision-making abilities. If there is a way of handling everyday contestations that does not have this kind of consequence, it seems preferable.

How about collective solutions? Here, one alternative would be a federalized system of corporate governance, such as, for instance, the German system of employee representatives on corporate boards. Let us call this the federal firm. Another approach would be some version of employee-run companies, such a cooperatives or other kinds of democratically run workplaces. Let us call this the employee-controlled firm (cf. Malleson 2013, 2014; Landemore and Ferreras 2016). Both approaches, however, share a similar characteristic, which makes them unsuitable as alternatives to unions, even if they, like the two individualist solutions above, could have aspects that speak in favor of them as complements to unions. They combine power rather than balance and check it. This is clearest in the case of employee-controlled firms. Even if the power of the company is wielded by the employees themselves, this power is centralized, and an internal system of contestability will still leave the individual employee vulnerable to this power. The employee-controlled firm combines two powers that should be balanced (e.g., the power of contestation and the power of authority). The federal firm is designed with the principle of the 
separation of powers in mind, but must be supplemented with unions to fully implement this principle. Even if the governance of the firm consists of both owners and employees, the firm acts as one agent, and even if this way of organizing the workplace lessens the risk of contestability being undermined, the interests of the firm and the individual will be distinct. Again, powers that should be separate and balanced are combined into one unique source of power. Unions will serve this balancing function by being organized outside the firm. Moreover, it may be the case that in order to implement the ideal of a federal firm in the most effective way, one must have unions. This would mean that even if firms should have federal structure, we have no reason to reject the argument for unions. These considerations justify the right to join a union, the principle of nondiscrimination against union members, and the ideal of good faith bargaining, even when other safeguards have been put in place.

\section{CONCLUSION}

This article has attempted to give a justification of unions based on the economics of contract and general liberal reasons from the Lockean tradition. Justifying unions has been understood as giving arguments to show that we have reason to support the right to join unions, the right of nondiscrimination, and the duty of good faith bargaining. The full argument has proceeded in three steps. First, I showed both the pros and cons of consent for such a project. I argued that there are circumstances where that theory can give a full justification of unions, but also other circumstances where unions will gain no support at all. During the second step, I tried to show that a theory of economic ethics needs further tools than consent, since it has trouble accounting for incomplete contracts, a problem which, in a sense, makes libertarianism incompatible with capitalism. In order to handle this problem, I suggested that we have reason to think of the justification of acts of employer authority in terms of contestability. I then showed that a way of implementing this notion was through unions. However, because there are other ways of implementing contestability, a further argument is needed to provide a unique justification of unions. The third step was devoted to providing this argument. The principle of the separation of powers demands that power is checked and balanced, and I showed that unions, being organized outside the bounds of the firm, are better suited to implement contestability than firm-internal ways of doing so. I conclude that unions have normative justification.

\section{ACKNOWLEDGEMENTS}

Earlier versions of this article were presented at the Royal Institute of Technology in Stockholm, the Swedish Philosophy Conference at Linköping University, a session on Work at the Mancept Workshops held at the University of Manchester, and Umeå University. Thanks to Per Wikman-Svahn, William Bülow, and Jesper Ahlin for particularly helpful comments. I would also like to thank the reviewers and editors of Business Ethics Quarterly for their very helpful questions, comments, and suggestions. Thanks as always to Kalle Grill and Niklas Möller. This research has been funded by the Swedish Research Council. 


\section{NOTES}

1. Friedman does not mention an often discussed further condition on consent - that the parties must be autonomous agents - and I will follow him in this. Autonomy is an important condition in some contexts, like health care, and may have implications even for the labor market, but I shall assume that if one is a party to an employment contract, then one is autonomous to a degree that satisfies such a condition.

2. See Olsaretti (1998) for an interesting line of egalitarian criticism against Nozick's approach to voluntariness and an alternative theory of voluntariness.

3. The reasoning in this section is spelled out in further detail in Lindblom (2009), which also discusses the conditions for consent, analyzed in the previous section, more extensively.

4. This is a kind of consequentialist explanation of employment contracts, which may seem in conflict with my focus on rights-based accounts of justification by consent. However, if one holds explanation and justification as distinct there is no contradiction.

5. For an interesting argument that the corporate firm cannot be owned, see Ciepley (2013).

6. Indeed, arguments for workplace democracy have been developed from these theoretical starting points. Singer (2017) takes asset specificity (i.e., the notion that investments in a workplace may be worth less outside that context) as the first step in such an argument. Moreover, it should be noted that there are rather compelling arguments to the effect that workers are in a comparative disadvantage with regards to employer due to the general structure of the labor market. Gourevitch's (2016) analysis of the right to strike uses and develops the notion of structural domination in an instructive way, which could potentially be used to further strengthen the argument put forward in this article. Since this approach falls outside the scope of the present article, the spelling out of such an argument will have to be the topic of another project.

7. Note that substantive norms have the same kind of relation to both consent and the account of contestability that will be discussed in the following sections of this article. A person can refuse to consent for substantial but bad reasons and he or she can contest for the same substantial bad reasons. The difficulty here has to do with the relationship between procedural and substantial reasons, and does not indicate a difference between contestability and consent that would speak in favor of the latter.

8. This is a very strong principle. On some weaker version, which, e.g., would say that consent lessens but does not eradicate morally relevant harm, there would be room for a more direct path to the justification of unions, especially in conjunction with the separation of powers considerations discussed in section 5 .

9. I thank a reviewer for Business Ethics Quarterly for raising this question.

10. It might seem that a way around the point I make here would be to say that one could devise contracts that set limits to authority. Contracts could say things like if the demands of the employer exceed some threshold consent is withdrawn. This may be an improvement over the status quo, but cannot solve the problem, since it will either be the case that the employer still has authority brought about by the problem of ignorance, or he or she will not have authority, in which case to solution boils down to not having employment contracts.

11. This argument will, in some readers, draw to mind the very important article by Hsieh (2005) on workplace republicanism. There are two important differences between Hsieh's argument and the one I put forward here. My argument does neither start from a general Rawlsian perspective, nor does it use the republican account of liberty as a premise.

12. I said in the introduction that there is little philosophical work done on unions, but Gourevitch's (2016) work on the right to strike is a notable exception. It contains many arguments that it would be important to discuss when investigating the implications of the theory that the present article aims to justify.

13. One could think that recreating the situation prior to the entry into the employment contract is not enough to ensure that there is no coercion. For instance, both prior to and during the employment relationship the employer could say that unless terms are agreed to the workplace will be closed and the jobs moved abroad. In relation to such a possible objection it is important to note two things. First, the theory proposed is consistent with egalitarian political philosophies that would demand redistribution to handle this kind of situation, and as long as they include a place for employment contracts they will have to turn to contestability as a complement to such policies. Second, as was mentioned in the introduction and will be returned to in the following chapter of the article, it may well be the case that unions as an institution bring about more equal distributions of income and wealth in which case unions indirectly provide a means to lessen or avoid coercion that depends on unequal bargaining positions. 
14. For an analysis of company unions, see Kaufman (2016; cf. Dray 2010). One could have imagined other approaches to compare unions to. In particular, high performance work systems would seem a plausible such candidate with its focus on team involvement and participation. I have chosen to focus on company unions for two reasons. The first reason is the instructive similarity between unions and company unions. The second reason is that the analysis of both will for the same reasons of separation of powers lead to the same conclusion that we have reason to prefer actual unions. For a description and analysis of high performance work systems, see Godard (2004).

15. Quoted from Federalist Papers No. 47 (Rossiter 1961, 303, emphasis is Madison's). The original in a different translation can be found in Montesquieu $(2011,52)$

16. For a discussion on the right to strike, see Gourevitch (2016).

17. Of course, it is also the case that the employer has the power to agree or not agree to the terms to the employment contract, but since our focus here is on employer demands and contestability, we can focus our attention on these two powers.

\section{REFERENCES}

Allen, Douglas W. 2000. "Transaction Costs." In Encyclopedia of Law and Economics, Volume I. The History and Methodology of Law and Economics, edited by Boudewijn Bouckaert and Gerrit De Geest, 893-926. Cheltenham: Edward Elgar.

Beauchamp Tom L., and James F. Childress. 2001. Principles of Biomedical Ethics, 5th ed. Oxford: Oxford University Press.

Bowles, Samuel. 2004. Microeconomics: Behavior, Institutions, and Evolution. Princeton: Princeton University Press.

Brousseau, Eric, and Jean Michel Glachant. 2002. "The Economics of Contract and the Renewal of Economics." In The Economics of Contracts, edited by Eric Brousseau and Jean Michel Glachant, 3-30. Cambridge: Cambridge University Press.

Cahuc, Pierre, Stéphane Carcillo, and André Zylberberg, A. 2014. Labor Economics, $2^{\text {nd }}$ ed. Cambridge: MIT Press.

Ciepley David. 2013. "Beyond Public and Private: Toward a Political Theory of the Cooperation." American Public Science Review 107: 139-158.

DePillis, Lydia, and Jim Tankersley. 2015. “To Fix Inequality, Democrats Are Pushing Unions." Washington Post, March 13.

Dray, Philip. 2010. There is Power in a Union. New York: Anchor Books.

Feinberg, Joel. 1984. Harm to Others. New York: Oxford University Press.

Feinberg, Joel. 1986. Harm to Self. Oxford: Oxford University Press.

Friedman, Milton. 1962. Capitalism and Freedom. Chicago: Chicago University Press.

Friedman, Milton, and Rose D. Friedman. 1990. Free to Choose: A Personal Statement. Orlando: Harcourt.

Galbraith, John Kenneth. 1993. American Capitalism: The Concept of Countervailing Power. New Brunswick: Transaction Publishers.

Godard, John. 2004. "A Critical Assessment of the High-Performance Paradigm." British Journal of Industrial Relations 42: 349-378.

Goodin, Robert. 2006. "Volenti Goes to Market." The Journal of Ethics 10: 53-74.

Gourevitch, Alex. 2016. "Quitting Work but Not the Job: Liberty and the Right to Strike." Perspectives on Politics 14: 307-323.

Hayek, Friedrich A. 1960. The Constitution of Liberty. London: Routledge \& Kegan Paul.

Hsieh, Nien-hê, 2005. "Rawlsian Justice and Workplace Republicanism.” Social Theory and Practice 31: 115-142. 
ILO. 1948. Freedom of Association and Protection of the Right to Organise Convention, 1948 (No. 87). http://www.ilo.org/dyn/normlex/en/f?p=NORMLEXPUB:12100::: NO:12100:P12100_ILO_CODE:C087:NO

ILO. 1949. Right to Organise and Collective Bargaining Convention, 1949 (No. 98). http:// www.ilo.org/dyn/normlex/en/f?p=NORMLEXPUB:12100:::NO:12100:P12100_ ILO_CODE:C098:NO

Jaumotte, Florence, and Carolina Osorio Buitron. 2015. "Power from the People." Finance \& Development 52: 29-31.

Kant, Immanuel. 1983. Perpetual Peace and Other Essays. Indianapolis: Hackett.

Kaufman, Bruce E. 2016. "Experience with Company Unions and their Treatment under the Wagner Act: A Four Frames of Reference Analysis." Industrial Analysis: A Journal of Economy and Society 55: 3-39.

Knight, Frank. 1921. Risk, Uncertainty, and Profit. Boston: Houghton Mifflin.

Landemore, Hélène, and Isabelle Ferreras. 2016. "In Defense of Workplace Democracy: Towards a Justification of the Firm-State Analogy." Political Theory 44: 53-81.

Lindblom, Lars. 2009. Consent, Contestability and Employer Authority." Revue de Philosophie Économique 10: 47-79.

Locke, John. 1980. Second Treatise of Government. Indianapolis: Hackett Publishing. Luce, R. Duncan, and Howard Raiffa. 1957. Games and Decisions. New York: Wiley.

Malleson, Tom. 2013. "Making the Case for Workplace Democracy: Exit and Voice as Mechanisms of Freedom in Social Life." Polity 45: 604-629.

Malleson, Tom. 2014. After Occupy: Economic Democracy for the 21st Century. Oxford: Oxford University Press.

McMahon, Christopher. 1994. Authority and Democracy. Princeton: Princeton University Press.

McMahon, Christopher. 2013. Public Capitalism: The Political Authority of Corporate Executives. Philadelphia: University of Pennsylvania Press.

Milgrom, Paul, and John Roberts. 1992. Economics, Organization and Management. Upper Saddle River: Prentice Hall.

Montesquieu, Baron de. 2011. The Spirit of the Laws. New York: Cosimo Classics.

Nozick, Robert. 1974. Anarchy, State, and Utopia. New York: Basic Books.

Nozick, Robert. 1997. Socratic Puzzles. Cambridge: Harvard University Press.

Olsaretti, Serena. 1998. "Freedom, Force and Choice: Against the Rights-Based Definition of Voluntariness." Journal of Political Philosophy 6: 53-78.

Pettit, Philip. 1997. Republicanism: A Theory of Freedom and Government. Oxford: Oxford University Press.

Pettit, Philip. 2000. "Democracy, Electoral and Contestatory.” Nomos 42: 105-144.

Pettit, Philip. 2001. A Theory of Freedom. Cambridge: Polity Press.

Resnik, Michael D. 1987. Choices. Minneapolis: University of Minneapolis Press.

Rosenfeld, Jake. 2014. What Unions No Longer Do. Cambridge: Harvard University Press. Rossiter, Clinton, ed. 1961. The Federalist Papers. New York: Mentor Books.

Saad, Lydia. 2015. “Americans' Support for Labor Unions Continues to Recover." Gallup. com, August 17, 2015. http://www.gallup.com/poll/184622/americans-support-laborunions-continues-recover.aspx.

Singer, Abraham A. 2017. "The Corporation as a Relational Entity." Polity 49: 328-351.

Solow, Robert. 2015. "The Future of Work: Why Wages Aren't Keeping Up." Pacific Standard, Aug 11, 2015. https://psmag.com/the-future-of-work-why-wages-aren-tkeeping-up-6fcfac468e 4. 
Vandenberghe, Ann-Sophie. 2000. “Labor Contracts.” In Encyclopedia of Law and Economics, Volume III. The Regulation of Contracts, edited by Boudewijn Bouckaert and Gerrit De Geest, 541-560. Cheltenham: Edward Elgar.

White, Stuart. 2013. "Association, Freedom of." In The International Encyclopedia of Ethics, edited by Hugh LaFollette, 373-382. Malden, MA: Wiley-Blackwell.

Yates, Michael D. 2009. Why Unions Matter, $2^{\text {nd }}$ ed. New York: Monthly Review Press.

Zuckert, Michael. 2012. "On the Separation of Powers: Liberal and Progressive Constitutionalism.” Social Philosophy and Policy 29: 335-364. 